\title{
THE OCTOBER MEETING IN WASHINGTON
}

The five hundred thirty-eighth meeting of the American Mathematical Society was held at the National Bureau of Standards in Washington, D. C., on Saturday, October 26, 1957. The meeting was attended by about 205 persons, including 155 members of the Society.

By invitation of the Committee to Select Hour Speakers for Eastern Sectional Meetings Professor W. H. Gottschalk of the University of Pennsylvania delivered an address entitled Minimal sets: An introduction to topological dynamics at a general session presided over by Professor Samuel Eilenberg.

Sessions for contributed papers were held in the morning and afternoon, presided over by Drs. L. W. Cohen, Philip Davis, Arthur Grad, W. H. Pell, and Professor R. A. Good. Abstracts of the contributed papers will appear in the February, 1958 issue of the Notices of the Society.

R. D. Schafer

Associate Secretary 